\title{
人 格部門
}

\section{心理尺度に着目したこの一年の概観 ーパーソナリティ研究とは「心理尺度づくり」なのだろうか ? -}

\author{
山口陽弘 \\ (群馬大学教育学研究科)
}

\section{はじめに〜本稿で論じる範囲について}

本稿で求められている課題は，この一年間 $(2009$ 年 7 月から 2010 年 6 月) のパーソナリティ領域の論文を概観し, 展望を加えることである。今回対象としたのは 2010 年 教育心理学会総会発表論文集に加元, 上記一年間に公刊 された『教育心理学研究』『心理学研究』『パーソナリ ティ研究』である。

昨年の人格部門を執筆した大芦（2010）によると，ま ず最初に問題となったのが人格部門の研究範囲であった という。大芦は結局明確な基準を設けず, 漠然とした自 身の心理学観に基づいて取捨選択したと述べている。筆 者にとってもこれは同じ問題であり,さらに過去 5 年間 の『教育心理学年報』(第 45〜第 49 集) を参照した。しか し，大芦と同様に人格部門の明確な基準を，各論者が設 けていたわけではなかった。あれこれ考光たが，これは 一種の擬似問題であると筆者は判断した。最終的に自身 の主観的な心理学観に支えられて分類する部分は, ぞう

しても残る。

そうも言っていられないので，なるだけ機械的に分類 しやすく, かつ現在のパーソナリティ研究の方向性に一 石を投じることも考えて作ったのが，「何らかの心理尺 度（質問紙が主）を個人差变数として実験, 調査で作成・ 利用したもの」という定義である。ただし，なるだけ 「パーソナリティらしい」構成概念の心理尺度に限定す る。しかし結局, この「パーソナリティらしい」という のが定義が難しいのだが。

このような定義を便宜的に作った理由は，一つには 『パーソナリティ研究』第 18 巻第 $1 \sim 3$ 号（注『パーソナ リテイ研究』は,第 18 巻としてきりがいいので 2009 年 6 月 30 日発 行の第 18 巻第 1 号も今回の分析に含めた）を概観し，その共 通点が，上記の定義ではないかと思われたためである。 掲載論文のほとんどが，何らかの心理尺度を作成あるい は利用しており，一年間全 31 本の論文中で，特定の心 理尺度が出現しないのは 4 本のみであった。そのうち 3 本はレビュー論文で，1本（ショートレポート）のみが面 接時の発話分析であり，いわゆる質問紙による心理尺度 を使用していない。つまり，レビュー論文を除いた研究
論文の 28 本中 27 本 $(96.4 \%)$ が何らかの心理尺度を作成 したり，利用したりしていた。以上の経緯から，議論の 範囲を限定するために，『パーソナリティ研究』で主要 な研究スタイルを, 人格部門研究と捉えておくことにす る。

しかし, 副題でも示しているように, 心理尺度づくり がパーソナリティ研究であると, 素朴に筆者が考えてい るわけではない。心理尺度とは無縁のパーソナリティ研 究も無論存在する。上述の例外例のように, 発話分析・ 行動分析などのたとえば質的な研究がそうである。ある いは心理尺度づくりではあっても, 知識やイメージの構 造分析であり, パーソナリティ研究とは言い難いものも 存在する。本稿では本来質的研究などにも目配りをする 必要があるのだろうが，今回問題提起する意味で，あえ て心理尺度に関する研究に限定して概観することにした。

この視点で『心理学研究』『教育心理学研究』を概観 すると, 前者は 49 本中 24 本 $(49.0 \%)$, 後者は 38 本中 22 本 $(57.9 \%)$ で，何らかの心理尺度を作成あるいは利 用していた（いずれも展望論文などのレビュー論文は母数から除 いた)。相対的に『心理学研究』に比較し, 『教育心理学 研究』の方が心理尺度を利用したものがやや多く, 全体 の論文の中で半数を越えている。以上の論文に加えて, 2010年の教育心理学会総会発表論文集中で，心理尺度を 作成あるいは利用した研究を本論の対象と限定して論じ ることにする。

なお, 総会発表論文集ほかには, 質的研究の文脈での M-GTA を利用したもの, 分析手法でも順序構造分析 や IAT (潜在連合テスト) やPAC 分析, テキストマイニ ング技法を駆使した，心理尺度を使用していない興味深 いパーソナリティ研究が数多くあったが, 上述の理由と 紙幅の都合で割愛させていただいた。ご寛恕を乞う。

\section{I 、論文を分ける枠組み}

次に問題となるのが，分類の視点である。これも過去 5 年間の年報では, 自己意識, アイデンティティ, 自尊 感情など, 構成概念の意味に着目し, 類似したグループ でまとめている論者が多かった。それも有効な一つの枠 
組みだが，本稿ではより原理的な枠組みを提示したいと 考えた。その際, 榎本 (2006), 都筑 (2009), 大芦 (2010) のものが原理的な枠組みを提示していて参考に なった。その中でも大芦 (2010) は,〈包括的・全体的〉 対〈個別的・局所的〉という横軸と〈体系・理論化志向〉 対〈問題理解・解决志向〉という縦軸とを設定し，四つ の象限を作成し, 各研究を位置づけている。

本稿では，この大芦のものを参考にし，ごく単純に二 つに分け「(1)心理尺度を新たに作ることを目的にした研 究」と「(2)心理尺度を利用した研究」とに分けて考える ことにした。大芦の縦軸に近い視点である。つまり，新 しい構成概念を測定するため，尺度を新たに作ることに 研究の重心が置かれている場合と, 何らかの目的のため に心理尺度を利用した研究とに分けるのである。もちろ ん，(1)の極端な場合である「心理尺度を作ること自体が 目的である研究」は本来的には存在しないだろう。(1)の 典型のような研究でも, いずれ何らかの有効利用をされ るために，尺度は作成されるものであるからである。ま た(1)に分類した論文でも, 妥当性検証のために, ほかの 構成概念との基準関連妥当性を調べている場合がほとん どである。論文構成も, 予備調査（研究1）の段階では新

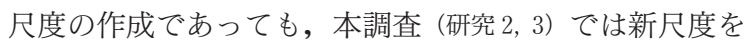
利用した研究である場合が多い。

しかし，当該論文に限定すれば，どこに力点が置かれ ているかはある程度弁別がつく。確かに(2)に限りなく近 い(1)や，分類する人の視点によっては(2)に入れた方がよ いと思われる場合も今回あった。最終的には筆者の主観 で分類したが，当該論文中で「**心理尺度の作成」を 行っているものは，原則的に(1)に該当することにした。

\section{II.「(1)心理尺度を新たに作ることを目的にした研究」}

この1)のタイプの研究が, その是非はともかく, パー ソナリティ研究の典型例と筆者は考える。この基準で以 下各誌からその尺度名を拾っていく。新たに作成（再検 討）された尺度はゴチックで示すことにした。

\section{1.『パーソナリティ研究』}

林田・佐藤（2009）が「自己憐憫尺度」，福森・小川 （2009）が「不快情動との直面促進要因尺度」, 長谷川・金 築・根建（2009）が「抑うつ的反すうに関するポジティブ な信念尺度」, 島（2010）が「改訂版 ECR（the Experiences in Close Relationships)-R の邦訳版」，薊（2010）が「恥・罪 悪感に関する感情尺度, 叱責者の特徵に関する尺度, 関 係修復反応尺度」, 桾本・山崎（2010）が「対人ストレス ユ一モア対処尺度」, 浅野 (2010) が「わりきり志向尺 度」, 高坂 (2010b) が「大学生における同性・異性・恋人 に対する期待項目尺度 $\rfloor$, 上野・高野・浅井・丹野 (2010)
が「日本語版オックスフォード統合失調型パーソナリ ティ尺度」, 丹羽・丸野（2010）が「自己開示尺度」，大 谷・中谷 (2010) が「中学生用自己価值の随伴性尺度」, 麻生・沼崎（2010）が「幸福感尺度」を新たに開発してお り，全部で 12 本の論文がある。『パーソナリティ研究』 であるがゆえに当然だが，全体の中で占める割合は，か なり多く(1)/(1)+(2)+それ以外）；12/28=42.9\%)，心理尺 度を作成あるいは利用しているものを母数とすると (1)/ (1)+(2) ； 12/27=44.4\%)，全体のほぼ半分近くの割合 を占めていることがわかる。

\section{2.『心理学研究』}

杉森・浅井・丹野（2009）が「健常者用幻聴様体験尺 度」, 浅井・高野・杉森・丹野 (2009) が「自己主体感尺 度」, 塚脇・樋口・深田（2009）が「ユ一モア表出尺度」, 越・関澤（2009）が「部活動内ソーシャルサポート測定尺 度」, 赤田（2010）が「保育士ストレス評定尺度」，高 野・野内・高野・小嶋・佐藤（2009）が「大学生の食生活 スタイル尺度」を作成しており, 安達（2010）は「キャ リア探索尺度」の再検討をしている。全部で 7 本である (1)/(1)+(2)+それ以外) ; 7/49=14.3\%)。『パーソナリティ 研究』よりはその割合が低い。しかし，心理尺度を作成 あるいは利用している研究を母数とすると (1)/(1)+(2)）; $7 / 24=29.2 \%)$ ，全体のほぼ三分の一である。

なお，『パーソナリティ研究』および『心理学研究』 で作成されている心理尺度群に一つの傾向はみいだしに くい。あえて言えば, 社会心理, 臨床心理, 教育心理各 領域にまたがる，有用性の高そうなものが，多く作成さ れているようである。

\section{3.『教育心理学研究』}

これも『心理学研究』と同様に，心理尺度を新たに作 成しているものに焦点を当て拾い上げると，以下の 6 本 となる。吉武（2010）が「中学生版生活満足度尺度（Students' Life Satisfaction Scale ; SLSS)」を日本語に翻訳し, あわせて「中学生版ポジティブ・イベント・チェックリ スト」を，竹村（2010）が介護福祉養成課程における実 習体験と介護への自己決定性の関係を調べるために, 「自己調整尺度」を，内海（2010）が中学生のネットいじ め，いじめられ体験を測定するために，「ネット統制尺 度」を作成している。秋光・白木（2010）は「養護教諭の 職務満足感尺度」を作成し，これと養護教諭のコーディ ネーション行動との関係を調べている。谷島（2010）は， 教師が学校コンサルタントに求める援助特性を調べるた めに，「教師が学校コンサルタントに対して求める援助 特性尺度」を作成し，それを「被援助志向性尺度，自己 効力感尺度，バーンアウト尺度」との関係から検証して いる。塚原 (2010) は「1 次/ 2 次コントロール尺度」を 
抑うつ回避のための Back/up モデルを検証するために 作成している。

以上の割合はほぼ『心理学研究』なみで (1)/(1)+(2)+ それ以外）; $6 / 38=15.8 \%$ ， 心理尺度を作成あるいは利用し ている研究を母数とすると（1)/(1)+(2)）；6/22=27.3\%)， やはり全体の三分の一近い。

\section{4.『総会発表論文集』}

総会発表論文集は, 特に尺度開発が主たる研究目的と 論文集に明記している場合に着目し，それらを(1)とみな し，その尺度名を以下に拾い上げた。ただし，独自開発 の尺度が含まれていても，それが研究の主たる目的でな いと判断される場合は入れなかった。その際, 項目文が ある程度記述されていること， $\alpha$ 係数等の基本統計量が 記述されていることなど, ある程度意義深いと判断され る論文を中心とした。

藤原（2010）「自立性支援的環境尺度」，斎藤・小川・矢 崎（2010）「コミュニ ケーションカ（りょく）尺度」, 山 中・荒木 (2010)「学校生活充実検査（ウェルライフ）」, 若 松 (2010)「進路の適合観点尺度」, 岡田・中谷・伊藤・大 谷（2010）「モデリング志向性尺度」, 畑野（2010）「学習 動機尺度」, 田中・三浦（2010）「母親の養育態度尺度」, 切替・沢崎（2010）「生命観尺度」, 中井 (2010)「生徒の母 親に対する信頼感 (STM) 尺度, 生徒の父親に対する信 頼感 (STF) 尺度」，大西・谷・大西・吉田・中島・松岡・ 望月・辻井（2010）「教師評定による中学生用学校適応尺 度」，小幡・村椿・健名・富家・坂野 (2010)「日本語版 BADS 尺度」, 劉・浦（2010）「中国の大学生の出世意欲尺 度」, 植村 (2010)「労働意欲尺度」, 井上・庄司 (2010) 「養護教諭の職業的アイデンティティ尺度」, 渡辺 (2010)「友人とのつながり意識尺度」, 織田・牧 (2010) 「教師の平等的態度尺度 $\rfloor$, 井内・藪内・田中 (2010)「コ ミュニケーション技術評価スケール」, 野中「非言語的 行動直接性尺度」, 江口・皆川（2010）「創造的態度尺度」, 牛山・芳川 (2010)「退職イメージ尺度」, 藤井 (2010)「母 親版子育て怒り尺度」, 中尾・原田（2010）「ママ友関連尺 度」, 野村・丸野 (2010) 「認識的信念尺度」, 工藤・小林 （2010）「社会性尺度」, 馬場・武蔵（2010）「社会性チェッ クリスト」, 楜澤 (2010)「養護性尺度」, 高坂 (2010a) $\lceil$ 共同体感覚尺度」, 澤田・葉山（2010）「正義一復讐尺度, 復讐心尺度」, 小浜（2010）「日本語版 PASS（先延ばし傾 向）尺度」, 高崎 (2010)「「ほめ」態度尺度」, 今野・土 肥・宮川・井上・相羽 (2010)「英語版 SIEM（モチベーショ ン教育システム) アセスメント尺度」, 麻生・岩立 (2010) $\lceil 母$ 親の乳児へのタッチ評定尺度」, 西野・大関・平川 （2010）「今の子供の姿と健康教育の必要性尺度」, 山本 （2010）「被援助感尺度」, 伊藤・若本 (2010)「学校現場で
求められる自尊感情尺度」, 久保嶋・沢崎（2010）「小学生 用障害観尺度 $」$, 藤原・濱口（2010）「高校生用聴くスキル 尺度」, 小川内・龍・光富・大塚 (2010)「学業的満足遅延 尺度」, 中谷 (2010)「日本語版 Identity Style Inventory」, 花岡・柴橋（2010）「友好的対話能力尺度」, 菱田・加藤・ 金子（2010）「自立性尺度」，佐藤（2010）「思春期心身発 達尺度」，村野（2010）「実習生・大学教員・実習先の先生 の目標構造尺度 $\rfloor$, 中岡・高田 (2010)「大学生への心理力 ウンセリングに対する援助要請意図尺度」, 三保・中谷・ 渥美・杉本・田中・大西・谷・並川・浦田・榎本・亀田 （2010）「大学進学理由尺度」, 中山・山田・小泉（2010）「教 師用規範行動尺度」, 小平 (2010)「保育版階層的大学コ ミットメント尺度」, 田中・有園（2010）「学級担任の関わ り行動尺度」, 以上 48 本の(1)に該当する研究があった。

『教育心理学研究』および「総会発表論文集」を概観 すると, やはり学校教育に関する心理尺度が多いようで ある。保育所から大学生，教師に関するものなど，その 調査対象に応じ細分化された心理尺度が目立つ。

\section{5. 新心理尺度の数の多さ, 整理の必要性}

以上各誌を眺めてきて，筆者自身の感想としては，心 理尺度を新たに作成する研究は，予想よりは少ないとい う印象を持った。実はもっと多いと思っており，具体的 には，少なくとも(1)と(2)との割合は，半々程度と予想し ていた。『パーソナリティ研究』に関してはそうであっ たが,『心理学研究』『教育心理学研究』では, (1)/ (1)+ (2)）は，全体の三分の一までに留まっている。無論，そ れも見方によっては高率ではある。総会発表論文集も， 全体の本数で考えれば，率は少ないかもしれないが，絶 対数は 48 本と多い。

何よりも，率は少なくとも「質」として類似のものが 多すぎるように思う。榎本（2006）は人格部門の概観を まとめるにあたり，同様な尺度の関連が不明なまま乱立 しており, それらを整備する必要性を指摘している。こ れは今でも通用する議論で，ここ十年の発表論文集を概 観しても同様な傾向が続いている。上述の尺度の中には, わざわざ各研究者が新たに作成せずとも，過去に同種の 心理尺度があるものが多数見受けられる。2010 年現在, 日本語での心理尺度は, 学術的に審査済みのものに限定 しても膨大な数にのぼる。しかもこれだけデータベース 化や，各種検索機能が充実してきている。新たな心理尺 度には，よほどの然るべき作成理由が必要だろう。あえ て新尺度を作成している場合は，失礼ながら当該研究者 による先行研究の検討が不十分であったり，あるいは非 常にトリビアルな構成概念を測定している可能性がある ように思う。後でも強調して触れるが, 新心理尺度が作 成される場合は, 過去の心理尺度の問題点が露呈し, 改 
訂する必要が生まれたときのみに限定されるべきではな いか。

\section{III.「(2)心理尺度を利用した研究」}

次は，心理尺度作成が主たる目的ではなく，心理尺度 を利用して別途の目的を果たそうとしている(2)の研究で ある。これは『心理学研究』『教育心理学研究』に絞っ て整理する（それ以外の雑誌に掲載されている論文は数が多いの で)。その際，心理尺度を何らかの目的で利用している のだから，その明確にさせたい目的が何なのか，どんな 心理尺度を利用したかを対にして短くまとめる。

\section{1.『心理学研究』}

『心理学研究』で, 何らかの心理尺度を使って各研究 者の目的を達しているものが以下の 17 本である。

伊藤・石井（2009） は，コラージュの変化を通してみた アルコール依存症者の病理性の調査のため「コラージュ 印象評定尺度（Collage Impression Scoring Scale ; CISS)」を 利用している。

服部・川口（2009）は，抑うつ者における思考抑制時の 侵入思考と注意の焦点化方略の関係の調査のため「ベッ ク抑うつ尺度（Beck Depression Inventory; BDI）」を利用し ている。

西野・小林・北川 (2009) は, 小学校高学年の抑うつと 自己価値の役割の関係を調べるため「ストレッサー尺度, ソーシャルサポート尺度, 自己価值尺度, 子ども抑うつ 尺度 (Child Depression Self-rating Scale ; CDSS)」を利用し ている。

関谷・湯川（2009）は，対人援助職者の感情労働におけ る感情的不協和経験の筆記開示を検証するため「自己評 価式抑うつ性尺度, 日本語版感情労働尺度, ネガティブ な反すう尺度, 日本語版バーンアウト尺度, 日本語版 TAS-20」を利用している。

趙・松本・木村 (2009) は, 公的自己と対人不安・自己 顕示への自尊感情を日韓比較するため「自尊感情尺度, 公的自己意識尺度, 対人不安尺度, 自己顕示性尺度」を 利用している。

佐々木・山形・敷島・尾崎・安藤（2009）は, 性役割パー ソナリティの個人差に及ぼす遺伝的・環境的性差の調査 のため「日本語版 BSRI 尺度」を利用している。

堀田・山岸（2010）が集団内の互恵性の調査のため「ア イデンティティ尺度」を利用している。

長谷川 (2010) は働く母親の移行期における日々の感 情経験の変化を調べるため「時間的切迫感, 活力, 親密 性, 抑うつ, 疲労感」の各尺度を利用している。

川人・堀・大塚 (2010) は大学生の抑うつ予防のために 介入プログラムを作成, その効果検証のため「抑うつ,
特性語分類課題，自尊感情」各尺度を測定・利用してい る。

山本・杉森・嶋田（2010）が自己注目時のネガティブな 認知的処理に及ぼす笑顔の効果を検証するため「特性不 安尺度, 感情状態尺度」を利用している。

笠置・大坊 (2010) が複数観衆問題への対処行動として の補償的自己高揚呈示を調べるため「自己呈示動機尺 度」を利用している。

渡部（2010）は高校生の主張性の 4 要件と友人関係に おける行動・適応との関連を調べるため「友人への主張 性, 友人への配慮行動, 対人不安尺度, 対人ストレスイ ベント尺度」を利用しており，特に前二者に関しては尺 度構成のための再分析も実施している。

藤・吉田（2010）は，オンラインゲーム上の対人関係が 現実生活の社会性・攻撃性に及ぼす影響の検証のため 「攻撃性尺度，対人ストレスイベント尺度，社会志向性 尺度，オンラインゲーム上での対人関係尺度」を一部作 成し，利用している。

松田・永作・新井（2010）は大学生の就職活動不安が就 職活動に及ぼす影響の検証のため「就職不安尺度，コー ピング尺度」を一部再構成, 利用している。

金井・佐々木・岩永・生和（2010）は社会不安のサブタ イプと生理的反応に対する認知の歪みの関係を検証する ため「社会不安を測定する尺度である SPS 日本語版, SIAS 日本語版，認知の歪みを測定するためにCBS」を 利用している。

川崎・小玉（2010）は，自己に対する受容的認知のあり 方からみた自己愛と自尊心の相違性を検証するため「対 人恐怖心性尺度，自己愛人格目録，自尊心尺度」を利用 している。

山崎・吉川（2010）は鳥インフルエンザに関する不安要 因の構造を，確認的因子分析によって分析している。本 論文は不安の構造分析であり，「心理尺度」研究と言い 難いがいくつかの因子に構成概念をまとめ，心理尺度構 成の手法を利用したものとして，ここに入れる。

\section{2.『教育心理学研究』}

『教育心理学研究』で，(2)に該当するものは全部で以 下の16本である。

浦上・小島・沢宮・坂野（2009）が男子青年における瘦 身願望の検討のため「瘦身願望尺度, 身体満足感尺度, 自尊感情尺度, 公的・私的自己意識尺度, 賞賛獲得・拒 否回避欲求尺度，異性意識尺度」を利用している。

細田・田嶌（2009）は中学生におけるソーシャルサポー トと自他への肯定感の検討のため「ソーシャルサポート 尺度，自己・他者肯定感尺度」を利用している。

大西・黒川・吉田 (2009) は，览童・生徒の教師認知が 
いじめの加害傾向に及ぼす影響を調べるため「いじめ加 害傾向尺度, 罪悪感尺度, 教師認知尺度, いじめへの学 級規範測定尺度」を利用している。

本田・大島・新井 (2009) は, 不適応状態にある中学生 への学級単位での社会的スキル訓練の効果を検証するた め「積極的な聴き方尺度, 中学生用社会的スキル尺度, 学級満足度尺度」を利用している。

一柳（2009）は，児童による話し合いを中心とした授 業における聴き方の特徵を調べるため「児童の聴く行為 についての評価尺度」を自身で作成・利用している。

濱口・石川・三重野（2009）は，中学生の能動的・反応 的攻撃性と心理社会的不適応との関連を調べるため「能 動的・反応的攻撃性尺度 (中学生用), 日本語版 CES-D 尺度, 反社会性行動欲求尺度」を利用している。能動 的・反応的攻撃性尺度は濱口の自作である。

岡田（2009）は, 部活動への参加が中学生の学校への 心理社会的適応に与える影響を調べるため「学校生活の 諸領域との関係の良さ尺度, 部活動への積極性尺度, 包 括的学校適応感尺度, 学校への不適応傾向尺度」を利用 している。学校への不適応傾向尺度以外は岡田自身の開 発である。

松本・山本・速水 (2009) は，高校生に扔ける仮想的有 能感といじめとの関係を調べるため「仮想的有能感尺度, 自尊感情尺度, 日常生活のいじめ経験尺度」を利用して いる。

石津・安保（2009）は中学生の過剩適応と学校適応の包 括的プロセスを調べるため「子ども用抑うつ尺度, 高校 生 (中学生) 用学校環境適応感尺度, 養育者態度尺度, 幼児用自己制御尺度」を利用している。

松沼 (2009) は, 受動態の学習における学習者の不十 分な知識とその修正について調べるため「構造の重要性 認知尺度, 文型の重要性認知尺度, 英文法学習意欲尺 度」を使用している。本論文は本稿で論じるよりは, 教 授学習分野で論ずるべきかもしれない。定義に基づくと 対象に入るので，一応入れておく。

加藤・大久保 (2009) は学校の荒れの収束過程と生徒指 導の変化調查のため「学校 (学級) の荒れ尺度, 問題行 動の経験尺度, 学校享受尺度, 教師との関係尺度, 不良 少年イメージ尺度，不公平な指導尺度」を利用している。 栗田・楠見（2010）は「障がい者」表記が身体障害者に 対する態度に及ぼす効果を調べるため「身体障害者イ メージ尺度，障害者への交流態度尺度」を利用している。 この「イメージ尺度」は自作である。この論文も人格部 門に入れにくいものだが，とりあえずここに分類してお く。

若本（2010）は，中年期の老いの自覚と対処における
「関心」の向け方を調べるため「関心〉尺度，Marlowe-Crowne 社会的望ましさ尺度，不安尺度（STAI）, 自尊感情尺度（Rosenberg），情緒不安定性尺度（Big5)」 を利用している。なお，〈関心〉尺度は自作である。

出口・木下・吉田（2010）は，「人間や社会に対する考元 方の基礎を養う」授業の効果検証のために，「ニア・ソシ オメトリックテスト，友人関係の取り方尺度，スクー ル・モラール尺度」を利用している。

清水・岡村 (2010) は, 対人恐怖心性一自己愛傾向 2 次 元モデルにおける認知特性を調べるために，「対人恐怖 心性一自己愛傾向 2 次元モデル尺度 (TSNS-S), ネガ ティブな反すう尺度, 完全主義尺度, 不合理な信念尺度, 自己嫌悪感尺度, 自己肯定感尺度, 自己関係づけ尺度」 を利用している。なお，TSNS-S は自作である。

永井（2010）は，大学生に㧍ける援助要請意図を調査 するため「大学生版ソーシャルサポート尺度, 自尊感情 脆弱性尺度, 自尊感情尺度, 抑うつ尺度 (CES-D)」を利 用している。

\section{3. 心理尺度を使った研究の二つのスタイル}

以上，羅列的な列挙で申し訳なかったが，これらの論 文を概観すると，次の二種類に分けられると考元た。こ れは(2)論文のみならず，(1)論文にも該当する。

第一のタイプは実験（介入）的操作を施して，その実 験効果の検証のために心理尺度を利用するものである。 いわゆる社会心理学的な実験や, 教育・臨床的な介入の 効果検証のために心理尺度を利用したものである。この 場合, 心理尺度はある程度, 信頼性と妥当性が認められ た既成のものを利用することが多い。ある実験（介入） という独立変数の結果を明らかにするために, 従属変数 として心理尺度を利用するものである。

第二のタイプは, 複数の構成概念間の「関係性」を明 らかにすることが目的の論文である。この複数の構成概 念を測定するために，既成の心理尺度（その中には自作の 新尺度が入ることが多い) を利用しているものである。その 多くが共分散構造分析などの多変量解析を利用し，構成 概念間のパス図を作成している。構成概念妥当性を検証 するために意味ネットワークを作成し，それを心理尺度 を利用し検証するものである。

第一のタイプの研究は, いわば古典的な社会心理実験 や教育・臨床的介入の効果を検証するものである。この 研究スタイルの問題は, パーソナリティ研究の持つ問題 というよりは，心理学自体の持つ根本的な方法論的問題 なので, その問題については本稿では論じない。

それに対して, 第二のタイプの研究が，どちらかと言 えば，パーソナリティ研究の「主流」とみなされ，時に 単なる心理尺度の寄せ集めの相関研究で，パーソナリ 
ティ研究への疑問を持つ論者から強く批判されることが 多いように思う。この批判については重要な問題を持つ と考えるので, 最後でまとめて論じる。総じて, 第二の タイプの研究が，『パーソナリティ研究』に特に多いよ うである。

\section{IV。しばしば利用される心理尺度〜整理の必要がある のではないか ?}

(1)と(2)の各論文についてかなり駆け足での紹介をした ので, 本節では心理尺度の構成概念の意味に着目して, 頻出するものを概観し，整理する。

多くの場面でしばしば利用されているのが，抑うつ尺 度である。これは実験（介入）的操作を行った際の効果 検証だけでなく，心理尺度を複数使った「関係性」検証 のためにも利用されている。特定の心理尺度に限定され ず CES-D，BDI，子ども用抑うつ尺度など，様々なも のが利用されている。(2)の中でも 8 本 $(8 / 33=24.2 \%)$ で 利用されている。

抑うつと同様に，類似の文脈でよく利用されているの が不安尺度である。これも特性不安, 状態不安, 友人へ の不安, 就職への不安と一種類ではなく多くの種類があ る。やはり実験（介入）の効果検証のみならず，複数の 心理尺度の中で重要な基準変数として利用されている。 あるいはビッグファイブの情緒不安定性などもこれに近 い形で利用されている。(2)の中でも広く考元れば同じく 8 本 $(8 / 33=24.2 \%)$ で利用されている。

このようなネガティブな心理尺度に限定されない幅広 い尺度として，自尊感情尺度もしばしば利用されている。 これは Rosenberg の翻訳版が多用されている。しかし， もともと自尊感情は構成概念としてその対象となる範囲 が広く (広すぎる?)，然るべき仮説なき利用は慎んだ方 がよいように思う。保険的に各研究者が利用していると 推測するが，その際も明確な利用目的，仮説が必要であ ろう。多くの尺度の一つとして利用されていることも， それを傍証しているようである。(2)の中でも 7 本（7/ $33=21.2 \%$ ）で利用されている。

それ以外ではソーシャルサポート尺度関係（コーピング やストレッサーも含めた)，攻撃性尺度，完全主義尺度，対 人恐怖心性尺度などが，この数年単位でみてもしばしば 利用されている。

二宮・杉山（2008）が，20 年前と現在（2007 年）を比較 し，パーソナリティ研究の変化を 3 点指摘している。 「1)ビッグファイブ研究に代表されるパーソナリティの 構造に関する研究がみられるようになった。(2) SEM (構造方程式モデル) などの新たな統計的手法によるデータ 分析を用いた研究がみられるようになった。(3)行動遺伝 学の知見からの影響がみられるようになった」。これ
は，いずれも 2010 年現在でもほぼ通用する指摘である。 特に(2)の共分散構造分析を利用したパス図は，パーソナ リティ研究の代名詞となっているかのようだ。

しかし，(1)のビッグファイブ研究はほぼ一段落し，現 在は利用される段階に移っていると思われる。現在では 特に(3)の行動遺伝学とも関連する形で, パーソナリティ の構造 (理論的背景にまで言及する) 研究が，ここ数年単位 でもホットなテーマであるように思う。この研究はまた, 行動遺伝学だけではなく, 気質・脳科学などの知見とリ ンクしてきてもいる。具体的には Gray の BIS/BAS, Cloningerの TCI などがその例である。この中で特に BIS/BAS などは，行動抑制系・行動賦活系の二つの気 質次元と生物学的基盤との関係について，これまで貧弱 であったパーソナリティの理論的背景に言及している点 で興味深い。

さて，複数の類似の構成概念を概観してきて，筆者が 非常に気になる点がある。たとえば複数存在する抑うつ 尺度の利用に際して，なぜその尺度を用いたのかという 言及がほとんどない点である。研究目的や対象者によっ て，当該尺度が選択されたと推測するが，その際，その 尺度の選択理由について，研究者に言及してほしいので ある。これは, 他の研究者にとってもその尺度利用の七 ントともなり，またその心理尺度（構成概念）の整理にも 繋がるからである。これまで概観しただけでも非常に多 くの心理尺度が毎年作成されている(三誌で 25 本, 総会発 表論文集で 48 本)。それ以外の各学術誌，この数十年で 生み出されてきた尺度の膨大な蓄積を考えれば，よほど 特殊なテーマ(「鳥インフルエンザへの不安」の構造分析がそ れ?) を除けば，類似の先行研究は，まずみいだせるは ずである。榎本 (2006) の指摘のように，「同じ概念を捉 える尺度であるなら同じような構成をとるのが自然であ り，あえて異なる構成をとるものが並立する場合はそれ ぞれの特徵や用途の違いが比較をもとに明示されている のが望ましい」。この観点での尺度のさらなる整理，あ るいは棲み分けを望みたい。

\section{$\mathrm{V}$ ，灷も炎もパーソナリティ研究は心理尺度づくりな} のだろうか? 〈今後の研究に望むこと〉

最後に，副題の疑問に戻る。ここまで便宜的に心理尺 度研究を, そのまま人格部門の研究と考えて話を進めて きた。しかし筆者は，パーソナリティ研究を心理尺度づ くりで事足れりとすることに，反対なのである。質問紙 での心理尺度研究に対し, 各研究者はもう少し疑問を 持ってほしいと兟越ながら思う。実はこの提言をしたい ために, あえて本稿のようなパーソナリティ研究の定義 を行い，概観してきたのであった。

質問紙研究には多くの批判がある。ここで須賀 
（2007）の批判を眺め，その意見に耳を傾けることにする。 須賀によれば「(1)質問紙法は, 診断の対象者が自己診断 するだけだから，単純で使用法も容易であるが，相貌心 理学のような客観性がない。しかも被検者が誠実に答え たことの保障がない。(2)被検者の誠実さには, 意識的な レベルの誠実さと無意識的なレベルの誠実さが区別され， そのどちらについても保障がない」。

須賀の主張は, 要するに自記式の質問紙法ではパーソ ナリティ理解は不可能だというものである。代案として, コルマンによる相貌学 (「顔」は客観的で性格と関連が深く, 予 測力が高い基準変数であるから?) を須賀は推奨している。 こうした批判に対し, 十分応えられる心理尺度研究を, まず自分が行ってきたかについて，筆者も反省する。

しかし, 今後も心理尺度は残っていくだろうし, 利用 価值はまだあると考えている。須賀の批判のよりどころ である「客観性」に着目して，可能な限りそれを満たす ようなパーソナリティ研究の方向性をささやかながら以 下提案したい。

客観的に観察可能な現象に着目するとすれば, マクロ な行動レベルでの同一個人の行動パターンこそパーソナ リティである。生態学的に妥当な場面において, 長時間 客観的な行動観察を行うことこそ, もつとも妥当な基準 変数である。その場合の基準変数は, 自記式の質問紙検 査ではなく, 他者などの複数のピア評定で, いわば チェックリストになる。それならば, 自記式の質問紙に 強い懐疑を抱く論者も納得してくれるだろう(パーソナリ ティなどそもそも存在しないという状況論者までは, 説得できるか ぞうかはわからないが)。

須賀の批判の矛先は，そもそも「自記式」への批判で あるように思う。しかし, 代案として須賀から提案され たコルマンの相貌学も, 筆者には難解でほとんど理解で きない。むしろ他者評定にも耐えうる項目分析をしてい くことが, 心理尺度を意味あるものに導くと筆者は考え る。

ではなぜ，心理尺度は自記式で利用されることが多い のだろう。「ユーザー」として素人が利用する分には， 自記式は悪いことではないと思われる。問題は妥当性検 証の際に,「プロ」の立場として, 心理学者が十分コス トをかけることを急ってきたことではないか。他にも， f-MRI を取ったり, 血液を取って遺伝子型を調べたり と, いわゆる「客観的」とされる各種脳科学・生理学的 手法をとることが, 近年有望視されている。結局はこの 領域で優れた「基準」をみいだすことが，陳腐な見解だ が，パーソナリティを含む人間の個人差変数解明へのブ レークスルーになるだろう。しかし，これらもまた，き わめてコストがかかり,「プロ」でなければできない手
法である。こうした面倒な妥当化の手続きをパーソナリ ティ心理学者は怠ってきたのではないか。実は, 上記の ようなコストを丁寧にかけることこそ，遠回りのようで 確実な, パーソナリティ研究の妥当性検証の方向ではな いだろうか。

須賀は, 税務署員や検察官は自記式の質問紙などに頼 らず，客観的な証拠に基づいて判断すると主張する。し かし，彼らが他の客観的証拠に頼るのは，コストがかけ られる場面であり，また反応歪曲が極端に起きやすい場 面だからである。自記式の質問紙法は，そもそもコスト を抑えるために開発された，必要悪としての簡便な手法 であり, 性善説に基づいている。実施者のメ夕認知能力 も前提としている。確定申告や, 裁判という場面は残念 ながらそうではないので, 質問紙は使用されないのであ る（細かいことだが, 確定申告も自記式に基づく部分が多いし, 裁 判も自白を重視するが…...)。

他の例で言えば，大学入試や企業の採用試験もそうで ある。何らかの自記式の質問紙法 (ペーパーテスト)を利 用しない大学, 企業はまずない（定員割れ等はひとまずお く)。それは能力検査かもしれぬが，これもやはり質問 紙法の一種である。面接場面も含めて, 受検者が入学希 望する場合，不当に回答を歪曲して自分を愚かにみせる 必要はない。逆に自分を賢くみせようと反応歪曲させて も，「賢い人」とそうでない人との弁別はある程度はつ くだろう。これは「コミュニケーション能力」などがま さにそうである。だから面接があるのである。

確かに「誠実性」などは質問紙では測定しにくいし， 面接, 観察でも弁別は難しいかもしれない。しかし，そ うした測定困難と思われる構成概念であっても，長期間 の行動観察で, 然るべき「プロ」がみれば弁別はつくだ ろう。要するにコストの問題なのである。また，そうい う「プロ」の目を持たぬ人間は, そもそも質問紙研究に は向いていないのではないか。

項目分析の手法からみても, 自己評定と他者評定との 間で違いが生じやすい項目こそ, 吟味すべきものである。 半世紀以上前から存在する MTMM（多重特性多重方法） などの手法を利用し, 弁別的妥当性と収束的妥当性を検 討すればよい。それが低い項目は, 尺度項目から除けば すむことなのである。現在では, MTMM どころか, 共分散構造分析などの多変量解析の手法が遥かに充実し ている。自記式に限定せず，他者評定（できれば複数で長 期間の）も取り入れて，妥当化の手続きに「コスト」を かけて項目を吟味していけば，質問紙はまだまだ活用で きる手法であろう。

反応歪曲が生じにくくなるような場面設定を第一にす ることも，質問紙 (チェックリストも) 実施に際して，前 
提条件となる。昔から言われているように，「ラポー ル」は調查協力者との間で必須である。ラポールが成立 していない状況では，自記式質問紙は怪しいのは当然で ある。要するに，自記式質問紙法は，実施者が自分の頭 を整理し，自分のことを調べ，理解したいという場合に 役立つ可能性があるにすぎない。

「客観的」なエビデンスを重視する論者にとつてみる と，自記式質問紙デー夕は，所詮は，本人が自分の認知 的構成物を吐露しているだけという批判もあろう。しか し, 質問紙法でパーソナリティを判定する研究者は, そ の人自身の認知的構成物に一定の意味があるという立場 を，積極的に採用しているのだと筆者は考えている。こ れはまさに G.A.Kelly のパーソナリティ理論である。 筆者自身は, Kelly やそれ以降に多く出現している社会 的構成主義者ほど，パーソナリティ＝認知的構成物であ ると考えているわけではない。パーソナリティには，相 当の脳科学的・生理学的根拠があると考えている。しか し, 質問紙を解釈する際には，そこに認知的構成物に よって説明される部分が，少なからず混入していること を認めねばなら奴ろう。もちろん，だからこそ質問紙 を峻拒する立場の人もいるだろう。

以上長々と述べてきたが，注意すべきは，質問紙（心 理尺度）への過信であり，「自記式」質問紙法の乱用で あろう。因子分析が統計パッケージ化されて，容易に利 用可能な道具となって久しい。しかし同時に，構成概念 の自動発生装置に陥っているという批判が時になされる。 現在では，それよりも遥かに強力な共分散構造分析が, 利用可能になってきている。これがともすると，構成概 念妥当性の自動検証装置として利用されている場合が少 なからずあるようだ。筆者自身，査読者の立場で，学術 誌への投稿論文の共分散構造分析のモデルを数多く眺め てきた。その際，GFIが低い方が不思議なほど，数多 くの「自記式」による変数を組み込んだ, 複雑かつ当た り前の，何を「検証」したか不明なモデルが多かったよ うに，失礼ながら思う。

それを防ぐためにも，質問紙検証の方法として，既に 述べたような，どこかに実験的な介入などの客観的で明 確な独立変数を入れて研究するスタイル (これは実は社会 心理学の古典的手法である) は，今もって有効だろう。ある いは客観的な生理的・脳科学的な基準变数（従属変数）を 取ってもよい。つまり，心理尺度の妥当性検証の際に， 自記式 $\times$ 自記式で構成概念妥当性を共分散構造分析で検 証されても，筆者には不十分に思えるのである。この場 合も，他者評定などの何らかの客観的変数（あるいは fMRI などでなくてもよいが,「理論的基盤」があるものが望まし い）との参照を可能にするモデルで検証してほしいので
ある。

最後に一言述べれば，最近，筆者自身が教育現場に行 くことが多いから思うのだが，上記のような「客観的」 なチェックリストづくりは，教育評価などの領域で，パ フォーマンス評価なども利用した，「真正の評価」をす るのと同様な発想である。そのために優れたルーブリッ クを作成することと同じことであろう。

そのためには，各種尺度の作成以前に，人間への「見 立て」が，研究者によってきちんとされねばならないと しみじみ感じる。それを可能ならしめるためには，各研 究者が，確固たる構成概念への実在感を持つことが先決 だろう。当該構成概念を，さながら数学者が虚数の実在 を実感するように感じるのならば，自ずと優れた心理尺 度は作成できるだろう。心理尺度の結果から，心理学者 が構成概念の実在を感じるというのは明らかに逆転して いるように思う。

\section{引用 文 献}

安達智子（2010）。キャリア探索尺度の再検討 心理 学研究, 81, 132-139.

赤田太郎 （2010)。保育士ストレス評定尺度の作成と 信頼性 心理学研究, 81, 158-166.

秋光恵子・白木豊美 (2010)，チーム援助に関するコー ディネーション行動とその基盤となる能力・権限が養 護教諭の職務満足感に及ぼす影響 教育心理学研究, $58,34-45$.

浅井智久・高野慶輔・杉森絵里子・丹野義彦 (2009)。自

己主体感を測定する尺度の開発と因子構造の探索 心 理学研究, 80, 414-421.

浅野憲一 (2010)。わりきり志向尺度の作成掞よび精 神的健康, 反応スタイルとの関係 パーソナリティ研 究, 18, 105-116.

麻生奈央子・沼崎 誠 (2010). 潜在・顕在的なロマン ティック幻想と結婚満足感 パーソナリティ研究, 18 , 244-247.

麻生典子・岩立志津夫 (2010)。乳児に対する母親の

タッチと精神的健康との関連 教心, 52, 628 .

薊理津子 (2010)。屈辱感, 羞恥感, 罪悪感の喚起要 因としての他者の特徵 パーソナリティ研究, 18 , 85-95.

馬場広充・武蔵博文 (2010)。学校教師が記入する社会 性チェックリストの課題＼cjkstart教心, 52,550 .

趙 善英・松本芳之・木村 裕 (2009)。公的自己意識 と対人不安, 自己顕示性の関係への自尊感情の調節効 果の日韓比較 心理学研究, 80, 313-320.

出口拓彦・木下雅仁・吉田俊和 $(2010)$.「人間や社会に 
対する考え方の基礎を養う」授業の効果に対する実験 的検討 教育心理学研究, 58, 198-211.

江口倫子・皆川直凡（2010）。览童期後期における創造 的態度が物語創作に与える影響 教心, $5 \mathbf{2}, 426$.

榎本博明 (2006). 人格心理学領域における研究動向 教育心理学年報, 45, 61-71.

藤 桂・吉田富二雄 (2010). オンラインゲーム上の対 人関係が現実生活の社会性および攻撃性におよぼす影 響 心理学研究, 80, 494-503.

藤井義久 (2010). 子育て中における母親の怒り感情 を高める要因に関する研究 教心, 52, 476 .

藤原健志・濱口佳和 （2010）。高校生用聴くスキル尺度 作成の試み(1) 教心, 52, 654 .

藤原善美 （2010）。 ライフコース展望の自立性支援的 環境 教心 $\mathbf{5 2}, 223$

福森崇貴・小川俊樹 （2009）。青年期における不快情動 との直面を促進する要因に関する研究 パーソナリ ティ研究, 18, 12-20.

濱口佳和・石川満佐育・三重野祥子 (2009). 中学生の 能動的 - 反応的攻撃性と心理社会的不適応との関連 - 2 種類の攻撃性と反社会的行動欲求および抑うつ傾 向との関連一 教育心理学研究, 57, 393-406.

花岡真弥・柴橋祐子 (2010). 友好的対話能力尺度の作 成 教心, 52, 657 .

長谷川 晃・金築 優・根建金男 (2009). 抑うつ的反 すうに関するポジティブな信念の確信度と抑うつ的反 すう傾向との関連性 パーソナリティ研究, 18, 21-34. 長谷川有香 (2010). 働く母親への移行期における時 間配分の調整過程と日々の感情経験の変化 心理学研 究, 81, 123-131.

畑野 快 (2010). 青年期後期の大学生を対象とした 学習動機尺度作成の試み 教心, 52,310 .

服部陽介・川口 潤 (2009)。抑うつ者における思考抑 制時の侵入思考と注意の焦点化方略の関係 心理学研 究, 80, 238-245.

林田太郎・佐藤 純 (2009)。青年期における自己憐憫 の構造一自己憐憫尺度作成の試み一 パーソナリティ 研究, 18, 1-11.

菱田陽子・加藤礼子・金子劭榮 （2010）。現代青年の自 立性に関する研究 教心, 52, 658 .

本田真大・大島由之・新井邦二郎 (2009). 不適応状態 にある中学生に対する学級単位の集団社会的スキル訓 練の効果一ターゲット・スキルの自己評定，教師評定， 仲間評定を用いた検討一 教育心理学研究, 57 , 336-348.

細田 絢・田嶌誠一（2009）。 中学生におけるソーシャ
ルサポートと自他への肯定感に関する研究 教育心理 学研究, 57, 309-323.

堀田結孝・山岸俊男 (2010). 集団内における互恵性の 適応基盤 心理学研究, 81, 114-122.

一柳智紀 (2009). 児童による話し合いを中心とした 授業における聴き方の特徵一学級と教科による相違の 検討一 教育心理学研究, 57, 361-372.

石津憲一郎・安保英勇 (2009). 中学生の過剰適応と学 校適応の包括的なプロセスに関する研究一個人内要因 としての気質と環境要因としての養育態度の影響の観 点から- 教育心理学研究, 57, 442-453.

井上美紀・庄司一子 (2010)。養護教諭の職業的アイデ ンティティ尺度の開発 教心, 52, 377 .

伊藤美奈子・若本純子 (2010)。学校現場で求められる 自尊感情を測る尺度作成の試み 教心, 52, 639 .

伊藤 満・石井雄吉 (2009). コラージュの変化を通し てみたアルコール依存者の病理性 心理学研究, 80 , 215-222.

井内伸栄・藪内順子・田中あゆみ (2010). 実習経験が 看護学生のコミュニケーション技術に及ぼす影響 教 心, 52,414 .

金井嘉宏・佐々木晶子・岩永 誠・生和秀敏 （2010）。社 会不安のサブタイプと生理的反応に対する認知の歪み の関係 心理学研究, 80, 520-526.

笠置 遊・大坊郁夫 (2010). 複数観衆問題への対処行 動としての補償的自己高揚呈示 心理学研究, 81 , 26-34.

加藤広通・大久保智生 (2009)。学校の荒れの収束過程 と生徒指導の変化一二者関係から三者関係に基づく指 導へ一 教育心理学研究, 57, 466-477.

川人潤子・堀 匡・大塚泰正 (2010). 大学生の抑うつ 予防のための自己複雑性介入プログラムの効果 心理 学研究, 81, 140-148.

川崎直樹・小玉正博 （2010）。自己に対する受容的認知 のあり方から見た自己愛と自尊心の相違性 心理学研 究, 80, 527-532.

切替史夏・沢崎真史 (2010). 思春期における攻撃的言 語表現と生命観との関連＼cjkstart教心, 52, 330 .

桾本知子・山崎勝之 (2010). 対人ストレスユーモア対 処尺度 (HCISS) の作成と信頼性, 妥当性の検討 パーソナリティ研究, 18, 96-104.

小平英志 $(2010)$. 大学適応の階層性に関する研究 教心, $\mathbf{5 2}, 759$.

小浜 駿 (2010). 日本語版 PASS 作成の試み 教心, 52, 561 .

今野紀子・土肥紳一・宮川 治・井上行雄・相羽千州子 
(2010). モチベーション志向英語教育システムの活 用 教心, 52, 621 .

越 良子・関澤敬子 (2009). 中学生の部活動適応感に おける部活動内ソーシャル・サポートの機能 心理 学研究, 80, 345-351.

久保嶋博子・沢崎真史 (2010). 小学校における発達障 害の理解教育に関する一研究 教心, 52, 651 .

工藤 弘・小林 武 (2010). 不登校を激減させた方法 教心, $\mathbf{5 2}, 532$.

栗田季佳・楠見 孝 (2010).「障がい者」表記が身体 障害者に対する態度に及ぼす影響—接触経験との関連 から一 教育心理学研究, 58, 129-139.

楜澤令子 （2010）。児童期における養護性 nurturance 尺度の検討 教心, 52,556 .

劉 暢・浦 光博 (2010). 中国の大学生の出世意欲に 及ぼす社会階層と職業意識の影響 教心, 52,371 .

松田侑子・永作 稔・新井邦二郎 (2010). 大学生の就 職活動不安が就職活動に及ぼす影響—コーピングに着 目して一 心理学研究, 80, 512-519.

松本麻友子・山本将士・速水敏彦 (2009). 高校生にお ける仮想的有能感といじめとの関連 教育心理学研 究, 57, 432-441.

松沼光泰 (2009). 受動態の学習における学習者の不 十分な知識とその修正 教育心理学研究, 57, 454-465. 三保紀裕 - 中谷陽輔 - 渥美純子 - 杉本英晴 - 田中道弘 大西将史・谷 伊織・並川努・浦田 悠・榎本博明 亀田 研 (2010). 生涯発達における自己の諸相(7) 教心, 52, 734 .

村野香織 (2010). 保育実習環境の目標構造が実習生 の目標志向に及ぼす影響 教心, 52,671 .

永井 智 (2010). 大学生に打ける援助要請意図一主 要な要因間の関連から見た援助要請意図の規程因一 教育心理学研究, 58, 46-56.

中井大介 (2010). 中学生の親に対する信頼感と学級 適応感との関連 教心, 52,347 .

中尾達馬・原田友紀 (2010). 育児中の母親だけが経験 する特異的な人間関係（ママ友関係）の諸特徵 教 心, 52, 480 .

中岡千幸・高田 純 (2010). 大学生の心理カウンセ ラーへの援助要請意四尺度の作成 教心, 52,722 .

中谷陽輔 (2010). Identity Style Inventory 日本語版 (ISI-J) 作成の試み(1) 教心, 52, 656 .

中山和彦・山田洋平・小泉令三 (2010). 学校生活にお

ける児童の規範行動測定 教心, 52, 744 .

二宮克美・杉山佳菜子 (2008). 人格研究の 1 年間の歩 み 教育心理学年報, 47, 80-89.
西野美佐子・大関信隆・平川昌宏 (2010). 教師が把握 する児童の健康実態と健康教育への取り組みの必要性 について(1) 教心, 52, 630 .

西野泰代・小林佐知子・北川朋子（2009）。高学年児童 の抑うつに対する社会環境の影響と自己価值の役割 心理学研究, 80, 252-257.

丹羽 空・丸野俊一 (2010). 自己開示の深さを測定す

る尺度の開発 パーソナリティ研究, 18, 196-209.

野村亮太・丸野俊一 (2010)。認識的信念尺度の作成 教心, 52,498 .

野中陽一朗 (2010)。教育実習を通じた非言語的行動 スキルに対する意識変容 教心, 52,416 .

小幡昌志・村椿智彦・健名広樹 - 富家直明 - 坂野雄二 (2010). 高校生における行動活性化と抑うつ, ソー シャルスキルの関係＼cjkstart教心, 52, 355 .

織田明日樹 - 牧 郁子 (2010). 教師平等感・受容性・

要求性が児童の学級適応に与える影響 教心, 52,409 . 小川内哲生・龍 祐吉・光富 隆・大塚一徳 (2010). 学 業的満足遅延尺度作成の試み 教心, 52,655 .

岡田 涼・中谷素之・伊藤崇達・大谷和大 (2010). ピ ア・モデリングの個人差を捉える試み 教心, 52, 307. 岡田有司 (2009). 部活動への参加が中学生の学校へ の心理社会的適応に与える影響 教育心理学研究, 57 , 419-431.

大芦 治 (2010). 人格に関する研究の動向と課題 教育心理学年報, 49, 77-85.

大西彩子・黒川雅幸・吉田俊和 （2009）。览童・生徒の 教師認知がいじめの加害傾向に及ぼす影響—学級の集 団規範およびいじめに対する罪悪感に着目して一 教 育心理学研究, 57, 324-335.

大西将史・谷 伊織・大西彩子・吉田琢哉・中島俊思・ 松岡弥玲・望月直人・辻井正次 (2010). 教師評定 による中学生用学校適応尺度の作成(1) 教心, 52, 350 . 大谷和大・中谷素之 (2010). 中学生用自己価值の随伴 性尺度の作成 パーソナリティ研究, 18, 233-236.

斎藤和志・小川一美・矢崎裕美子 (2010). コミュニ ケーション力 (りょく) 尺度作成の試み（I）教心 $\mathbf{5 2}, 252$.

佐々木掌子・山形伸二・敷島千鶴・尾崎幸謙・安藤寿康 (2009)。性役割パーソナリティ（BSRI）の個人差に 及ぼす遺伝的性差・環境的性差 心理学研究, 80 , 330-338.

佐藤睦子 (2010). 思春期の心身発達に関する小学生 と中学生の比較研究 教心, 52, 659 .

澤田匡人・葉山大地 (2010). 裁判員としての量的判断 に及ぼす復讐心の影響 教心, 52, 560 . 
関谷大輝・湯川進太郎 (2009). 対人援助職者の感情労 働における感情的不協和経験の筆記開示 心理学研 究, 80, 295-303.

島 義弘 (2010). 愛着の内的作業モデルが対人情報 処理に及ぼす影響一語彙判断課題による検討 パーソ ナリティ研究, 18, 75-74.

清水健司・岡村寿代 (2010). 対人恐怖心性一自己愛傾 向 2 次モデルにおける認知特性の検討一対人恐怖と社 会恐怖の異同を通して一 教育心理学研究, 58, 23-33. 須賀哲夫 (2007). 顔立ちとパーソナリティ一相貌心 理学からみた日本人一 北大路書房

杉森絵里子・浅井智久・丹野義彦 （2009）。健常者用幻 聴様体験尺度（AHES）の作成および信頼性・妥当性 の検討 心理学研究, 80, 358-396.

高野裕治 - 野内 類 - 高野春香 - 小嶋明子・佐藤眞一 (2009). 大学生の食生活ス夕イル一精神的健康及び 食行動異常との関連— 心理学研究, 80, 321-329.

高坂康雅 （2010a）。共同体感覚尺度の作成 教心， 52, 557.

高坂康雅 (2010b). 大学生における同性友人，異性友 人，恋人に対する期待の比較 パーソナリティ研究， 18, 140-151.

高崎文子 (2010). 「ほめ」構造とその効果 4 教心, 52, 589 .

竹村明子 (2010). 実践教育の効果一介護福祉士養成 課程における実習体験と介護への自己決定性の関係一 教育心理学研究, 58, 176-185.

田中千穂・三浦香苗 $(2010)$ ， 母親の養育態度に関する 研究 2 教心, 52, 322 .

田中哲二・有園博子 (2010). 学級の荒れ行動に対する 生徒の意識と学級担任の関わり行動との関係 教心, 52, 770 .

谷島弘仁 (2010). 教師が学校コンサルタントに求め る援助特性に関する検討 教育心理学研究, 58, 57-68. 塚原拓馬 (2010)。 1 次/ 2 次コントロールにおける $\mathrm{Back} / \mathrm{up}$ モデルの検証一尺度作成と否定的事態に対 するコントロール方略の作動関係— 教育心理学研 究, 58, 186-197.

塚脇涼太・樋口匡貴・深田博已 (2009). ユーモア表出 と自己受容, 攻撃性, 愛他性との関係 心理学研究, 80 ,
339-344.

都筑 学 (2009). 人格に関する研究の動向と課題 教育心理学年報, 48, 95-104.

植村善太郎 (2010)。仮想的有能感と勤労観および労 働意欲との関連 教心, 52,376 .

上野真弓・高野慶輔・浅井智久・丹野義彦 (2010)。 日 本語版オックスフォード統合失調型パーソナリティ尺 度の信頼性と妥当性 パーソナリティ研究, 18 , 161-164.

浦上涼子・小島弥生・沢宮容子・坂野雄二 （2009）。男 子青年における瘦身願望についての研究 教育心理学 研究, 57, 263-273.

牛山幸世・芳川玲子 (2010)。定年退職の捉え方と時間 的展望に関連する背景要因 教心, 52, 457 .

内海しょか (2010). 中学生のネットいじめ,いじめ られ体験一親の統制に対する子どもの認知，および関 係性攻撃との関連一 教育心理学研究, 58, 12-22.

若松養亮 (2010). 大学生の進路意志決定における適 合の判断 教心, $5 \mathbf{2}, 292$.

若本純子 (2010). 中年期の老いの自覚と対処におけ る「関心」の向け方による相違 教育心理学研究, 58 , 151-162.

渡部麻美 （2010）。高校生の主張性の 4 要件と友人関 係における行動および適応との関連 心理学研究, 81 , 56-62.

渡辺弘純 (2010). 中学生における友人とのつながり 意識に関する研究 教心, 52,394 .

山本 奨 （2010）不登校児童生徒を支援する教師の 自己効力感 教心, 52, 636 .

山本哲也・杉森伸吉・嶋田洋徳 (2010). 自己注目時の ネガティブな認知的処理に及ぼす笑顔の効果 心理学 研究, 81, 17-25.

山中真実・荒木紀幸 (2010)。通常学級に在籍する発達 障害児のための学校生活充実検査（ウエルライフ） の開発 教心, 52,278 .

山崎瑞紀・吉川肇子 (2010). 鳥（新型）インフルエン ザに関する不安要因 心理学研究, 80, 476-484.

吉武尚美 (2010)。 中学生の生活満足度に関連するポ ジティブ・イベントーイベントの項目収集と相互影響 関係の検討一 教育心理学研究, 58, 140-150. 